\title{
MINAT IBU MELAKUKAN STIMULASI TUMBUH KEMBANG ANAK USIA 1-5 TAHUN DESA MARON KECAMATAN BANYAKAN KABUPATEN KEDIRI
}

\author{
Susiani Endarwati ${ }^{1}$, Cendikia Haqiqi ${ }^{2}$ \\ ${ }^{1,2}$ Akademi Kebidanan Dharma Husada Kediri Jawa Timur
}

\begin{abstract}
Abstrak
Stimulasi adalah perangsangan yang datangnya dari lingkungan luar individu anak, anak yang banyak mendapatkan banyak stimulasi akan lebih cepat berkembang. Data Dinas Kesehatan Jawa Timur 2014 jumlah angka cakupan deteksi dini tumbuh kembang anak balita dan prasekolah tingkat Jawa Timur pada tahun 2014 sebesar 54,8 \%. Sedangkan cakupan data Dinas Kesehatan wilayah Kabupaten Kediri pada tahun 2016 mencapai 6,38\%. Tujuan dalam penelitian ini adalah untuk mengetahui minat ibu melakukan stimulasi tumbuh kembang anak usia 1-5 tahun.

Desain penelitian ini menggunakan desain penelitian deskriptif. Populasi adalah Semua Ibu Balita Di Dusun Maron Desa Maron Kecamatan Banyakan Kabupaten Kediri. Teknik sampling yang digunakan adalah total sampling. Sampel yang digunakan dalam penelitian ini adalah semua ibu balita di Dusun Maron Desa Maron Kecamatan Banyakan Kabupaten kediri. Pengambilan data menggunakan kuesioner kemudian dilakukan pengolahan data dengan cara editing, coding, scoring, tabulating. Selanjutnya data dianalisis mengunakan prosentase.

Hasil penelitian Ketertarikan ibu termasuk kategori tinggi yaitu 54 responden (100\%) Perhatian ibu temasuk tinggi yaitu 51 responden (94,4\%) Motivasi ibu termasuk tinggi yaitu 47 responden $(87,7 \%)$ Pengetahuan ibu termasuk tinggi yaitu 49 responden $(90,7 \%)$

Berdasarkan hasil penelitian minat responden adalah tinggi. Untuk lebih memperkuat minat tersebut, responden banyak memerlukan informasi dan dukungan yang lebih dari keluarga dan Bidan. Peneliti menyarankan hendaknya Bidan selalu memberikan informasi yang terkait tentang stimulasi tumbuh kembang anak pada responden melalui penyuluhan.
\end{abstract}

Kata Kunci : Minat, Stimulasi Tumbuh Kembang, Anak

Korespondensi: Jl. Penanggungan No.41-A Kediri Jawa Timur HP.085646667282 Email : susianiendarwati1@gmail.com 


\section{Pendahuluan}

Anak merupakan dambaan setiap keluarga, selain itu setiap keluarga juga mengharapkan anaknya kelak bertumbuh kembang optimal (sehat fisik, mental, dan sosial), dapat dibanggakan serta berguna bagi nusa dan bangsa (Soetijiningsih 2014:2). Kualitas seorang anak dapat dinilai dari proses tumbuh kembang. Proses tumbuh kembang merupakan hasil interaksi faktor genetik dan faktor lingkungan.

Faktor genetik/keturunan adalah faktor yang berhubungan dengan gen yang berasal dari Ayah dan Ibu, sedangkan faktor lingkungan meliputi lingkungan biologis, fisik, psikologis, dan sosial (Chamidah, 2016:36).

Pertumbuhan dan perkembangan memiliki pengertian yang sama-sama mengalami perubahan, namun secara khusus keduanya berbeda. Pertumbuhan menunjukan perubahan yang bersifat kuantitas sebagai akibat pematangan fisik yang ditandai dengan makin kompleksnya sistem jaringan otot, sistem syaraf serta berfungsi sistem organ tubuh yang lainnya dapat diukur, akibat kematangan organ fisik siap melaksanakan tugas dan aktivitas sesuai dengan tahapan stimulasi perkembangan individu. (Yuniarti, 2015:4) Menurut Attila (2008) Dalam arti sederhana, tumbuh berarti bertambahnya ukuran-ukuran tubuh: seperti bertambahnya berat badan, tambah tinggi dan tambah lingkar kepalanya. Sedangkan kembang berarti anak tambah pintar dan nakal. (Maryunani, 2010:36)

Stimulasi adalah perangsangan yang datangnya dari lingkungan luar individu anak, anak yang banyak mendapatkan banyak stimulasi akan lebih cepat berkembang dari pada anak yang kurang atau tidak mendapat stimulasi, semaki dini semakin cepat stimulasi dilakukan, makan akan semakin besar manfaat terhadap tumbuh kembang bayi balita (Maryunani, 2010:86) Stimulasi merupakan salah satu upaya untuk mencerdaskan anak. Stimulasi harus dilakukan sedini mungkin, bahkan sejak dalam kandungan. Sebaiknya dilakukan stimulasi terhadap semua aspek perkembangan dengan melibatkan ibu atau anggota keluarga lainnya (Soetijiningsih 2014:211).

Berdasarkan Depkes RI, 2016 bahwa 19,3\% balita Indonesia mengalami gangguan perkembangan, baik perkembangan motorik halus dan kasar, sosial kemandirian, kecerdasan kurang dan keterlambatan. Menurut Standar Pelayanan Minimal Provinsi Jawa Timur, angka cakupan deteksi dini tumbuh kembang anak balita dan prasekolah tingkat Jawa Timur pada tahun 2014 sebesar 54,8 \% (Dinkes Jawa Timur, 2014) Sedangkan cakupan data Dinas Kesehatan wilayah Kabupaten Kediri pada tahun 2016 mencapai $6,38 \%$. Cakupan deteksi dini tumbuh kembang anak balita dan prasekolah untuk wilayah Puskesmas Tiron pada tahun 2016 mencapai 4,8 \%.(Dinkes Kabupaten Kediri, 2016)

Berdasarkan hasil studi pendahuluan yang dilakukann pada tanggal 19 April 2017, di Desa Maron Kecamatan Banyakan Kabupaten Kediri dilakukan pada 15 ibu yang mempunyai anak usia 1-5 Tahun dengan metode wawancara, didapatkan hasil $11 \mathrm{ibu}(73.3 \%)$ tidak berminat melakukan stimulasi tumbuh kembang dan $4 \mathrm{ibu}$ $(26,7 \%)$ lainnya masih mempunyai minat yang kurang dan hanya menyerahkan stimulasi tumbuh kembang padaposyandu

\section{Metode}

Penelitian ini menggunakan desain penelitian deskiftif dengan perdekatan cross sectional. Populasi dalam penelitian ini adalah semua ibu yang mempunyai Anak Usia 1-5 Tahun Di Dsn. Maron Desa Maron Kecamatan Banyakan Kabupaten Kediri. Dengan Teknik Total Dampling didapatkan sampel 54 Responden. 
Hasil

a. Karakteristik Responden Berdasarkan Pendidikan

Tabel IV.1: Karakteriatik Responden Berdasarkan Pendidikan Di Dusun Maron Desa Maron Kecamatan Banyakan Kabupaten Kediri.

\begin{tabular}{clccc} 
No & & Pendidikan & Jumlah & Presentase (\%) \\
\hline 1 & SD & 5 & 9,3 \\
\hline 2 & SMP & 17 & 31,5 \\
\hline 3 & SMA & 30 & 55,5 \\
\hline 4 & DIPLOMA/SARJANA & 2 & 3,7 \\
\hline & & 54 & 100
\end{tabular}

Berdasarkan tabel IV.I dari 54 responden yang diteliti, sebagian besar responden berpendidikan SMA yaitu 30 responden $(55,5 \%)$.

b. Karakteristik Responden Berdasarkan Pekerjaan

Tabel IV.2: Karakteriatik Responden Berdasarkan Pekerjaan Di Dusun Maron Desa Maron Kecamatan Banyakan Kabupaten Kediri.

\begin{tabular}{clcc} 
No & \multicolumn{1}{c}{ Pekerjaan } & Jumlah & Presentase (\%) \\
\hline 1 & Tidak bekerja (IRT) & 43 & 80 \\
\hline 2 & Petani & 1 & 2 \\
\hline 3 & PNS & 1 & 2 \\
\hline 4 & Swasta & 8 & 15 \\
\hline 5 & Wiraswasta & 1 & 2 \\
\hline \multicolumn{2}{r}{ Jumlah } & 54 & 100
\end{tabular}

Berdasarkan tabel IV.2 dari 54 responden yang diteliti, sebagian besar responden tidak bekerja (IRT) sebanyak 43 responden $(80 \%)$

c. Karakteriatik Responden Berdasarkan Informasi

Tabel IV.3: Karakteriatik Responden Berdasarkan Informasi Di Dusun Maron Desa Maron Kecamatan Banyakan Kabupaten Kediri.

\begin{tabular}{llcc} 
No & Jumlah Informasi & Jumlah & Presentase (\%) \\
\hline 1 & Pernah & 50 & 92,6 \\
\hline 2 & Tidak Pernah & 4 & 7,4 \\
\hline & Jumlah & 54 & 100
\end{tabular}

Berdasarkan tabel IV.3 54 responden yang diteliti, sebagian besar responden pernah mendapatkan informasi yaitu 50 responden $(92,6 \%)$ 


\section{d. Karakteristik Responden berdasarkan Sumber Informasi}

Tabel IV.4: Karakteriatik Responden Berdasarkan Sumber Informasi Di Dusun Maron Desa Maron Kecamatan Banyakan Kabupaten Kediri.

\begin{tabular}{lllcc} 
No & \multicolumn{2}{c}{ Sumber Informasi } & Jumlah & Presentase (\%) \\
\hline 1 & Media Cetak (Koran) & 4 & 7,4 \\
\hline 2 & $\begin{array}{l}\text { Media Elektronik } \\
\text { Internet) }\end{array}$ & 3 & 5,5 \\
\hline 3 & Teman & Radio, & 3 & 5,5 \\
\hline 4 & Tenaga Kesehatan & 44 & 81,6 \\
\hline \multicolumn{2}{c}{ Jumlah } & 54 & 100
\end{tabular}

Berdasarkan tabel IV.4 diketahui bahwa dari 54 responden, yang diteliti didapatkan 44 responden $(81,6 \%)$ mendapat informasi dari tenaga kesehatan.

e. Distribusi Frekuensi Minat Ibu Melaukan Stimulasi

Tabel IV.5: Minat Ibu Melakukan Stimulasi Tumbuh Kembang Anak Usia 1-5 Tahun Di Dusun Maron Desa Maron Kecamatan Banyakan Kabupaten Kediri

\begin{tabular}{ccccc} 
No & & Minat & Jumlah & Presentasi (\%) \\
\hline 1 & Tinggi & 53 & 98,1 \\
\hline 2 & Sedang & 1 & 1,9 \\
\hline 3 & Rendah & 0 & 0 \\
\hline & & 54 & 100
\end{tabular}

Berdasarkan tabel IV.5 dari 54 responden yang diteliti didapatkan 53 reponden $(98,1 \%)$ memiliki minat tinggi dan 1 responden (1,9\%) memiliki minat sedang dalam melakukan stimulasi tumbuh kembang anak usia 1-5 tahun di dusun Maron Desa Maron Kecamatan Banyakan Kabupaten Kediri.

f. Distribusi Frekuensi Minat Ibu Melakukan Stimulasi Bedasarkan Indikator Minat

Tabel IV.6: Indikator Minat Ibu Melakukan Stimulasi Tumbuh Kembang Anak Usia 1-5 Tahun Di Dusun Maron Desa Maron Kecamatan Banyakan Kabupaten

\begin{tabular}{llcccccccc}
\multirow{2}{*}{ No } & \multirow{2}{*}{ Indikator Minat } & \multicolumn{2}{c}{ Tinggi } & \multicolumn{2}{c}{ Sedang } & \multicolumn{2}{c}{ Rendah } & \multicolumn{2}{c}{ Total } \\
\cline { 3 - 10 } & & $\sum$ & $\mathbf{\%}$ & $\sum$ & $\mathbf{\%}$ & $\sum$ & $\mathbf{\%}$ & $\sum$ & $\mathbf{\%}$ \\
\hline 1 & Ketertarikan & 54 & 100 & 0 & 0 & 0 & 0 & 54 & 100 \\
\hline 2 & Perhatian & 51 & 94,4 & 3 & 5,5 & 0 & 0 & 54 & 100 \\
\hline 3 & Motivasi & 47 & 87,7 & 7 & 13 & 0 & 0 & 54 & 100 \\
\hline 4 & pengetahuan & 49 & 90,7 & 5 & 9,3 & 0 & 0 & 54 & 100
\end{tabular}

Dari tabel IV.5 dapat diketahui bahwa dari 54 responden:

Diketahui dari 54 responden yang diteliti didapatkan 54 responden $(100 \%)$ memiliki ketertarikan tinggi.

Diketahui dari 54 responden yang diteliti didapatkan 51 responden $(94,4 \%)$ memiliki perhatian tinggi.
Diketahui dari 54 responden yang diteliti didapatkan 47 responden memeliki $(87,7 \%)$ memiliki motivasi tinggi.

Diketahui dari 54 responden yang diteliti didapatkan 49 responden memiliki $(90,7)$ memiliki pengetahuan tinggi. 


\section{Diskusi}

\section{Minat Ibu Melakukan Stimulasi Tumbuh Kembang Anak Usia 1-5 Tahun}

Berdasarkan hasil penelitian yang dilakukan bahwa minat ibu melakukan stimulasi anak usia 1-5 tahun dengan jumlah 54 responden yang diteliti didapatkan 53 responden $(98,1 \%)$ memiliki minat tinggi dan 1 responden $(1,9 \%)$ memeiliki minat sedang Di Dusun Maron Desa Maron Kecamatan Banyakan Kabupaten Kediri.

Minat merupakan sumber motivasi yang mendorong orang untuk melakukan apa yang mereka inginkan bila mereka merasa berminat. Faktor timbulnya minat seseorang terdiri dari 3 yaitu faktor dorongan dari dalam, faktor motivasi sosial, faktor emosiaonal (Suprayanto, 2011).

Alasan ibu balita tidak melakukan stimulasi pertumbuhan dan perkembangan anak yang berhubungan dengan minat seseorang. Minat akan timbul dari dalam diri seseorang dan dari pikiran terhadap sesuatu. Seorang ibu balita yang tidak melakukan stimulasi tumbuh kembang anak karena mereka tidak mengetahui apa keuntungan dan kerugian apabila melakukan stimulasi tumbuh kembang anak.

Dengan begitu melakukan stimulasi tumbuh kembang anak harus memiliki minat dalam melakukan stimulasi. Minat merupakan kecenderungan atau arah keinginan terhadap seseuatu untuk memenuhi dorongan hati, minat merupakan dorongan dari dalam diri yang mempengaruhi gerak dan kehendak terhadap sesuatu, dorongan kuat bagi seseorang untuk melakukan segala sesuatu dalam mewujudkan pencapaian tujuan dan cita-cita yang menjadi keinginannya (ketertarikan dalam suatu objek tertentu).

Hal-hal yang mempegaruhi minat antara lain: status ekonomi, pendidikan, situasional, keadaanpsikis. Kurangnya pengetahuan masyarakat mengenai pelayanan kesehatan akan mempengaruhi pemanfaatan fasilitas pelayanan yang ada sehingga berpengaruh pada kondisi kesehatan mereka (Suprayanto, 2011).
Perlu diketahui pengetahuan sangat erat hubungannya dengan pendidikan dimana diharapkan bahwa dengan pendidikan tinggi maka orang tersebut akan semakin luas pula pengetahuannya, dengan pendidikan ibu yang masih kurang dapat mempengaruhi tumbuh kembang anak. Seseorang ibu yang memiliki pendidikan tinggi akan cenderung lebih mudah mendapatkan informasi dari banyak cara, baik melalui orang lain ataupun melalui media cetak, media elektronik.

Makin tinggi tingkat pendidikan seseorang makin mudah menerima informasi sehingga diharapkan makan banyak pula pengetahuan yang dimiliki. Dapat diartikan bahwa pendidikan sangat mempengaruhi perilaku seseorang. Pendidikan diperlukan untuk mendapatkan informasi misalnya hal-hal yang menujung kesehatan sehingga dapat meningkatkan kesehatan dan kualitas hidup (Suprayanto, 2011).

Tumbuh kembang anak jika dilakukan sedini mungkin dapat meningkatkan kesehatan dan kulitas hidup karena ibu sudah mengetahui pentingnya stimulasi tumbuh kembang, ibu dapat langsung bertanya kepada tenaga kesehatan apakah anak tumbuh kembang secara optimal, karena tentunya kita semua mendambakan anaknya mengalami pertumbuhan dan perkembangan secara normal dan tidak mengalami gangguan pada tumbuh kembang anak.

\section{Simpulan}

Mengingat pentingnya peran penyuluhan kesehatan dalam meningkatkan pengetahuan, kesadaran serta perilaku kesehatan. Maka petugas kesehatan perlu memaksimalkan upaya dalam memberikan penyuluhan - penyuluhan kesehatan kepada para ibu khususnya ibu yang memiliki balita maupun ibu secara umum sehingga dengan pengetahuan yang baik akan meningkatkan minat yang positif pula. meningkatkan pengetahuan wanita usia subur tentang kanker ovarium. 


\section{Daftar Pustaka}

Ariani, 2014. Aplikasi Metodologi Penelitian Kebidanan Kebidanan Dan Kesehatan Reproduksi. Yogyakarta: Nuha Medika

Arikunto, Suharsimi. 2013. Prosedur Penelitian Suatu Pendekatan Praktik. Jakarta: Rineka Cipta.

Hidayat Alimul A., 2012. Riset Keperawatan Dan Tehnik Penulisan Ilmiah. Jakarta: Salemba Medika

2014. Metode penelitian kebidanan dan teknik penulisan data. Jakarta:salemba medika

Kemenkes RI, 2011. Pedoman Pelaksanaan Stimulasi, Deteksi dan Intervensi Dini Tumbuh Kembang Anakdi Tingkat Pelayanan Kesehatan Dasar. Jakarta

Maryunani Anik. 2010. Ilmu Kesehatan Anak Dalam Kebidanan. Jakarta : CV. Trans Info Media

Notoatmodjo Soekidjo. 2012. Metodologi Penelitian Kesehatan. Jakarta: Rineka Cipta.

Nursalam, 2013. Konsep Dan Penerapan Metodologi Penelitian Ilmu Keperawatan. Jakarta: Salemba Medika. 2016. Metodelogi Penelitian Ilmu Keperawatan. Jakarta: Salemba Medika

Sulistyaningrum dkk, 2013. Asuhan Keperawatan Bayi dan Anak untuk Bidan dan Perawat. Jakarta : Salemba Medika

Setiadi., 2013. Konsep Dan Praktik Penulisan Riset Keperawatan. Yogyakarta: Graha Ilmu.

Sugiono., 2010, Statistik Untuk Penelitian. Bandung: Alfabet.

Suharsimi, Arikunto. 2006. Prosedur Penelitian Suatu Pendekatan Praktik. Jakarta : PT. Rineka Cipta.

Sujarweni. 2014. Metode Penelitian. Yogyakarta : Pustaka Baru Pres
Soejiningsih, 2013. Tumbuh Kembang Anak, Edisi 2. Jakarta : EGC

Yuniarti dkk, 2015. Asuhan Neonatus, Bayi dan Balita.jakarta: Salemba Medika

Kamus Besar Bahasa Indonesia, 2008. Minat. [Online] (Update 2015). Diakses dari : http://kbbi.web.id/minat. [20 April 2017].

Suparyanto, 2011. Konsep Dasar Minat. Diakses dari $\quad$ : http://drsuparyanto.blogspot.co.id/2011/01/konsepdasar-minat.html? $m=1$ [28 April 2016]

Wikipedia, 2014. Teori Ibu [Online] (Update 2014). Diakses dari : http://id.m.wikipedia.org/wiki/Ibu. [12 April 2017]. 